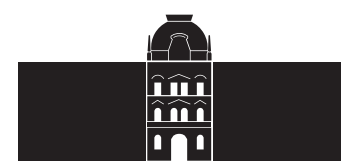

Univerzitetna založba Univerze v Mariboru

\title{
A Review of Tannins in Berries
}

\author{
Barbara BERNJAK, Janja KRISTL* \\ University of Maribor, Faculty of Agriculture and Life Sciences, Pivola 10, 2311 Hoče, Slovenia
}

\begin{abstract}
Tannins are a group of polyphenolic compounds synthesized and accumulated by higher plants as secondary metabolites. They are divided into hydrolysable tannins and proanthocyanidins and are found in many plant tissues in which they occur in diverse structures and amounts. This review provides a brief background on tannin distribution in plants, and summarizes the current literature on tannins in strawberries, raspberries, blueberries, currently the most commonly cultivated and consumed berries, and chokeberries, which have become popular in the last decades. The effects of processing and storage on tannin composition and levels in processed products are also provided.
\end{abstract}

Key words: ellagitannins, proanthocyanidins, strawberry, raspberry, blueberry, chokeberry

\section{INTRODUCTION}

Tannins belong to the complex phenolic compounds, defined as phenolic derivatives synthesized by higher plants as secondary metabolites. More than 8000 tannin compounds have been isolated and chemically characterized (Krzyzowska et al., 2017). Tannins are phenylpropanoid compounds often condensed to polymers of variable length (Swanson, 2003), which have molecular weights between 300 and 3000 daltons (Da) (Mena et al., 2015). They are unstable and can be converted into various compounds when the plant cells are damaged (for example, during processing of plant raw materials) (Izawa et al., 2010). Tannins are synthesized by many plant species and can be found mainly in roots, stems, bark, leaves, buds and seeds, where they take up 5 to $10 \%$ of dry vascular plant material (Barbehenn and Constabel, 2011).

Structurally, tannins are divided into two classes: hydrolysable and condensed tannins (Izawa et al., 2010). Hydrolysable tannins are water-soluble (Izawa et al., 2010), and include ellagitannins, gallotannins and also more complex tannins. The basic structure of hydrolysable tannin is a carbohydrate whose hydroxyl groups are esterified with phenolic acids, such as gallic acid (Khanbabaee and Van Ree, 2001).
The second group are proanthocyanidins (condensed tannins). They are the most abundant polyphenols in plants (Lamy et al., 2016). Condensed tannins are polymers of 2-50 flavonoid units, which are not susceptible to hydrolysis (Khanbabaee and Van Ree, 2001). Biosynthesis of proanthocyanidins requires products from the shikimate and acetate/malonate pathways. The starter and extension units of proanthocyanidins are generated via the flavonoid pathway, which shares the same upstream pathway with anthocyanidins, the substrates for anthocyanin synthesis. The key enzymes involved in this process are well known. Anthocyanidins can be catalysed by anthocyanidin reductase to produce flavan3-ols, important substrates for proanthocyanidin synthesis. Recent advances in understanding the molecular genetic basis of proanthocyanidin biosynthesis were described by Dixon and Sarnala (2020).

The majority of condensed tannins are water-soluble, exceptions are some molecules with higher molecular weight (Izawa et al., 2010). They are more resistant to microbial degradation and also show stronger antiviral, antifungal, and antibacterial activities (Krzyzowska et al., 2017). It was found that condensed tannins, from some legume species, can be beneficial for cattle and other ruminants, because they reduce the risk of flatulence caused by high-protein diets and internal parasite loads (Constabel et al., 2014). More than 
$90 \%$ of total tannins on the market are condensed tannins (Khanbabaee and Van Ree, 2001; Filgueira et al., 2017).

Tannins in foods cause astringent sensations and a bitter taste, and play an important role, due to their potential beneficial effects on human health (Lamy et al., 2016). The highest amounts of tannins have been reported in coffee, cocoa, chocolate, green and black tea, red wine, nuts, legumes, cereal grains, fruits and vegetables (Crozier et al, 2009; Smeriglio et al, 2017). Berries are characterised by high levels of micronutrients, vitamin C, folates (Di Vittori et al., 2018), polyphenols like anthocyanidins, which are responsible for the intense colour in many berries and many other antioxidant phytonutrients (Milivojević et al., 2011). Pre-harvest factors such as cultivar, cultivation practices, environment and plant age have a significant impact on commercial, organoleptic and nutritional quality in berries (Alvarez-Suarez et al., 2014). Light exposure is an important environmental factor with positive effects on flavonoid synthesis in raspberries (Wang et al., 2009), strawberries (Anttonen et al., 2006), grapes (Matus et al., 2009), and blueberries (Uleberg et al., 2012). However, blueberries accumulate high levels of anthocyanins even when grown in shaded sites, suggesting that the stimulation of flavonoid biosynthesis is cultivation and cultivar dependent (Di Vittori et al., 2018). In such fruits the biosynthesis of various flavonoids depends on the developmental stage of the fruit, while environmental factors have little influence. The content of anthocyanins in strawberries is more dependent on the ripening stage, while the accumulation of flavonols and proanthocyanidins is more sensitive to environmental factors (Carbone et al., 2009). The effects of light exposure and light wavelengths on flavonoid biosynthesis in fruits are described in detail in the review by Zoratti et al. (2015).

This paper reviews the distribution of tannins in plants with special attention to strawberries, raspberries and blueberries, which are the most widely grown and consumed berries in the EU (Oliveira et al., 2019), as well as in chokeberry, which has become popular in recent decades. The effects of processing and storage on the composition of ellagitannins and proanthocyanidins and their levels in berry products are also provided.

\section{DISTRIBUTION OF TANNINS IN PLANTS}

The most common composition of tannins in nature is a mixture of proanthocyanidins and hydrolysable tannins with the latter being present in lower quantities. There are some exceptions such as the Acacia sp. and Terminalia sp. species, which are an important source of condensed and hydrolysable tannins, and a few dicotyledons species (Furlan et al., 2010).

Tannins in plants occupy up to $20 \%$ of the dry weight (DW), ranking them after cellulose, hemicellulose and lignin. The synthesis of tannins in plants is often associated with defence responses against microbial pathogens, harmful insects, herbivores (Furlan et al., 2010) and UV-A or UV-B radiation. Polyphenols are stored in vacuoles and cell walls (Fraga-Corral et al., 2020). Because of this, tannins have been found in many plant tissues: wood, bark, roots, leaves, fruits, and seeds (Sieniawska and Baj, 2017).
The occurrence of tannins within plants varies widely among tissues, organs, cell types (Constabel et al., 2014) and varies among different species of the same genus (Prida and Puech, 2006). The accumulation of tannins is usually specific to certain cell types. During the development of $O$. viciifolia leaves, the condensed tannins shift from the abaxial to the adaxial side of the leaf and also into specialized cells in the epidermis (Lees et al., 1993). Specialized cells, which contain condensed tannins, have also been found in the phloem parenchyma in young poplars. In this case, condensed tannins accumulate in the hypodermal cells of older stems and in the epidermal cells of young stems (Kao et al., 2002). The accumulation tendency of condensed tannins into the epidermal layers has a protective function against pathogens and UV stress (Close and McArthur, 2002).

Considerable quantities of tannins are present in the roots of some woody plants. In $P$. tremuloides root tips, condensed tannins are localized in the cortex, lateral root cap and epidermal tissues (Kao et al., 2002), while in eucalyptus and jack pine they are found in a region between the suberized zone and root tip (Mckenzie and Peterson, 1995). Condensed tannins in seeds may contribute to the endosperm and embryo protection by blocking the movement of molecules that oppose seed dormancy prior to early germination and stress by serving as physical and chemical barriers (Lepiniec et al., 2006). High tannin content has been reported in seed coats of Phaseolus vulgaris and other beans (Jin et al., 2012), many nuts, sorghum cereal seeds and barley (Prior and $\mathrm{Gu}, 2005)$. Fruits containing high amounts of tannins continue to accumulate them until fully ripened, giving them a corresponding astringent taste, while fruits with low amounts of tannins stop their production at an early stage of development (Akagi et al., 2009).

\section{TANNINS IN BERRIES}

The term "berry" refers to small fruits growing in wild shrubs that can be bitter or sweet, with a juicy mesocarp, have an intense red, blue or purple colour or in some cases also a white colour (Hidalgo and Almajano, 2017). Berry fruits are usually used because of their special taste and attractive colour. They primarily include strawberry, blackberry, blueberry, raspberry, cranberry, elderberry, mulberry and currants, which are the most abundant berries worldwide (Manganaris et al., 2014; Di Vittori et al, 2018). Lesser known species also classified as berry fruits are: huckleberry, chokeberry, lingonberry, boysenberry, olallieberry, gooseberry, barberry, dewberry, juneberry, tayberry and exotic berries: açai berry, goji berry, physalis, cloudberry, pineberry and salmonberry (Leafy place, 2019).

\section{Strawberry}

More than 20 ellagitannins have been determined in fruits, leaves and roots of strawberry (Fragaria $x$ ananassa Duch.) (Gasperotti et al., 2013; Karlińska et al., 2021). They consist of glucose esterified with hexahydroxydiphenic acid (HHDP) and gallic acid (Aaby et al., 2012). Their content varies with 
cultivar, plant growth stage, and plant part. The synthesis and accumulation of ellagitannins are the most intensive in the leaves, however, a decreasing tendency in their content was observed throughout plant development (Karlińska et al., 2021). The growth stage is reported to have a greater effect on ellagitannin content in strawberry morphological parts than the cultivar (Karlińska et al., 2021), however, the opposite was reported for strawberry fruits of different cultivars grown in Italy (Gasperotti et al. 2013). The ellagitannin level of mature strawberry fruits varies from 6.53 to 52.38 $\mathrm{mg} / 100 \mathrm{~g} \mathrm{FW}$ (fresh weight) (Buendia et al. 2010; Nowicka et al., 2019; Karlińska et al., 2021). Studies have shown that the monomeric ellagitannins in strawberry fruits, roots and leaves are pedunculagin, casuarictin and potentillin. The main product of potentillin dimerization is agrimoniin, which has been found to prevail in strawberry fruits (Aaby et al., 2012; Nowicka et al., 2019), leaves and roots (Karlińska et al., 2021). Immature fruits have shown the highest contents of agrimoniin and those tended to decrease and reach lower values in fully mature fruits (Gasperotti et al., 2013; Aaby et al., 2012; Fecka et al., 2021), and even less agrimoniin was detected in overripe fruits (Gasperotti et al., 2013). Its mean values for 'Syrena', 'Pandora ISK', 'Selvik', and 'Elvira' cultivars vary from $0.17 \mathrm{mg} / \mathrm{g}$ in green fruits to $0.118 \mathrm{mg} / \mathrm{g}$ in pink and $0.111 \mathrm{mg} / \mathrm{g} \mathrm{FW}$ in red fruits (Fecka et al., 2021). Agrimoniin was proposed a s chemotaxonomic marker for Fragaria (Okuda et al., 1992). The levels of agrimoniin did not show large differences between 27 cultivars grown in Norway (Aaby et al. 2012) with the average value of 8.8 $\mathrm{mg} / 100 \mathrm{~g}$ FW, however, higher variability was observed for 90 cultivars grown in Poland, with the values in the range from 3.60 to $30.79 \mathrm{mg} / 100 \mathrm{~g}$ FW (Nowicka et al., 2019). Woodland strawberries (Fragaria vesca) contain higher contents of ellagitannins and ellagic acid conjugates when compared to cultivated strawberries (Gasperotti et al., 2013). The fragariin, sanguiin H-2, ellagitannin with MW 1718, and $\beta$-ellagitannin with MW 1718 are generally present in much lower concentrations. The ratio of monomeric and dimeric ellagitannins in leaves and roots is relatively equal, whereas in fruits the dimeric forms predominate (Karlińska et al., 2021). The majority of ellagic acid in strawberry fruits is found in a bound form as a part of ellagitannins and constitutes, together with conjugated derivatives, less than $5 \%$ of total phenolics (Buendia et al. 2010).

Aaby et al. (2012) reported that the most abundant class of polyphenolic compounds in mature strawberry fruits are anthocyanins, which account for $41 \%$ of the total phenolic content, followed by flavan-3-ols (28 \%) and ellagitannins (14\%). However, Buendia et al. (2010) found proanthocyanidins to be the predominant phenolic compounds in Spanish strawberry cultivars with the values ranging from 0.539 to $1.632 \mathrm{mg} / \mathrm{g}$ FW. Similar findings were reported for strawberry fruits (Fragaria $\mathrm{x}$ ananassa Duch.) grown in Trentino in which proanthocyanidins represented between 54.8 and $77.4 \%$ of polyphenolic compounds (Gasperotti et al., 2015). Proanthocyanidin profile in strawberry fruit is complex. The terminal flavan3 -ol in oligomers is (epi)catechin, and the extension units are (epi)catechin (60-70\% of the proanthocyanidins) and (epi)afzelechin (propelargonidin). It has been reported that the degree of polymerization varies within cultivars. It is proposed that cultivars characterized with higher contents of monomers and dimers can potentially have better biological activity, because they can be better absorbed than larger proanthocyanidins oligomers (Buendia et al. 2010). Many potential health effects of ellagitannins have been listed in the literature. Their effect on the brain's hippocampus is reducing the effect of aging in spatial orientation (Shukitt-Hale et al., 2007). They also influence the gastric epithelial cells by inhibiting the inflammatory response to TNF through NF-B dependent and independent mechanisms (Fumagalli et al., 2016), reduce the level of specific biomarkers for cardiovascular diseases, inflammation, blood pressure, lowers LDL cholesterol, controls glycaemia and promote antitumor activity in esophageal, lung and colon cancers (Desjardins, 2014). A more detailed discussion of potential biological functions of ellagitannins and their metabolites is provided in the review paper by Landete (2011).

Strawberries as well as other Rosaceae fruits are stored frozen or processed in purees, juices, syrups and jams, because of their short shelf life. It has been reported that the transfer of ellagitannins from fresh fruits to products depends on the technological process used. The production of purees seems to be superior to the production of juices, since 56 to $92 \%$ of the total ellagitannins present in fresh fruits are transferred to purees, while they are lost in juice production, were 65 to $90 \%$ are present. The losses have been attributed to the high molecular weight compounds (1871$2038 \mathrm{Da})$ that remain in pomace from unclarified juice production (Milczarek et al. 2021). It has been proposed that in the course of fruit processing, high molecular weight ellagitannins are depolymerized or degraded to conjugates, and that some ellagitannins could be exposed to hydrolysis leading to elevated ellagic acid levels in pomaces (Oszmiański and Wojdylo, 2009; Milczarek et al. 2021).

\section{Raspberry}

A major class of polyphenols in raspberries are ellagitannins which represent $53.5 \%$ to $75.9 \%$ of the total polyphenol content, with $100 \%$ being the sum of ellagitannins, anthocyanins, flavanols and flavonols (Mullen et al., 2002a; Sójka et al., 2016). Ellagitannins in raspberries are a mixture of monomeric and oligomeric tannins, which structure is characterized by ellagic and gallic acid moieties and sanguisorboyl linking ester group (Vrhovsek et al., 2006). Free ellagic acid represents a small fraction of the total ellagic acid released during hydrolysis of plant material, mainly from sanguiin H-6 and lambertianin C (Määttä-Riihinen et al., 2004; Mullen et al., 2002a). Relatively large variations in free ellagic acid (1.98-5.24 mg/kg FW) and total ellagitannins content (94.15-326 mg/100 g FW) have been reported for fruits of different cultivated raspberry ( $R$. idaeus) cultivars (Milivojević et al., 2010; Bobinaité et al., 2012; Smeriglio et al., 2017; Vrhovsek et al., 2008), with higher levels of free ellagic acid detected in wild Rubus berries (12.71 mg/kg), which are usually characterized with smaller fruits of a more intensive colour (Çekiç and Özgen, 2010).

The ellagitannin profile of raspberries usually consists of two 
compounds. The main ellagitannin present in red ( $R$. idaeus) and black ( $R$. occidentalis) raspberries is the dimer, sanguiin $\mathrm{H}-6$ with values ranging from 135 to $1743 \mathrm{mg} / 100 \mathrm{~g}$ DW and 1537 mg/100 g DW, respectively (Sparzak et al., 2010; Kula et al., 2016). The trimer, lambertianin $C$, which consists of six HHDP, three glucosyl and three galloyl moieties, occurs in much lower concentrations with notable differences between certain cultivars (Mullen et al., 2003; Kula et al., 2016). The sanguiin H-6 (5\% of DW) and also free ellagic acid (1\% of DW) dominate in shoots of $R$. idaeus which are commonly used in folk medicine as herbal remedies (Krauze-Baranowska et al., 2014). Proanthocyanidins are B-type polymers and are composed of catechin, epicatechin and epiafzelechin. Their content in raspberries amounts to $79 \mathrm{mg} / 100 \mathrm{~g} \mathrm{FW}$ (Gu et al., 2004) and prevail in seeds and in insoluble parts of the skin.

The total content of ellagitannins and proanthocyanidins in maturing raspberry fruit decreases as maturity approaches (Beekwilder et al., 2005). Beside cultivar and stage of maturity, the content of phenolic compounds, including tannins, depends on cultivation practices, environmental conditions, and storage time (Bobinaité et al., 2012; Mazur et al., 2014).

Raspberries are perishable soft fruits and are preserved by deep freezing or processed into juice, jam or syrup. The fruits are also preserved by various drying techniques such as hot air-drying, freeze-drying, microwave-drying, and hot pumpdrying. The advantages and disadvantages of these methods are discussed in the review paper prepared by Piccolo et al. (2020). The authors concluded that the freeze-drying method is most likely the best choice for the preservation of bioactive compounds. Industrial processing of raspberries into juice causes losses of bioactive compounds. This is a consequence of the processing conditions which result in a polyphenol transformation or degradation and changes in fruit morphological characteristics. An interesting study was published by Sójka et al. (2016) reporting that raspberry fruit juice, when compared to fresh fruits, retains on average $11.8 \%$ of ellagitannins. The majority of the ellagitannins remains in the press cake, especially in its seedless fraction, which is characterized by high levels of ellagitannins and proanthocyanidins. The phenolic composition of juices depends on the processed cultivar. The juice prepared from certain cultivars retains more anthocyanins and others more ellagitannins, when compared to fresh fruits. Further information highlighting the steps in juice processing, which cause significant losses and compositional changes of ellagitannins, are provided by Howard et al. (2012). The authors also discussed the possible mechanisms for ellagitannins losses during the processing into juices, purees, and canned products. Processing of raspberries into jams does not affect the ellagic acid glycoside content, which remains quite stable, while an increase in free ellagic acid content is usually observed, probably because of its release from ellagitannins with thermal treatment (Zafrilla et al., 2001). However, the content of total ellagic acid in raspberry jams is much lower, $23-36 \%$ of those being present in the unprocessed berries (Koponen et al., 2007; Zafrilla et al., 2001). When raspberries are frozen within 3 hours of harvest and stored at $-30{ }^{\circ} \mathrm{C}$ for short time (4-5 days), no discernible difference in lambertianin $\mathrm{C}$ and sanguiin $\mathrm{H}-6$ is observed, whereas storage of fruit at $4{ }^{\circ} \mathrm{C}$ for 3 days resulted in an increase in both ellagitannins (Mullen et al., 2002b). Therefore, consummation of freshly picked, freshly frozen or fresh commercial fruits, provides the intake of similar levels of phytochemicals. Prolonged storage in the freezer (one year) maintains total phenolics content, although ellagic acid decreases (De Ancos et al., 2000; Türkben et al., 2010).

\section{Blueberry}

The highest amount of polyphenols in blueberries (Vaccinium cormymbosum L.) represents flavonoids, especially 25 individual anthocyanins (1000 mg/100 g FW), while flavonols, flavan-3-ols and proanthocyanidins, follow in considerably lower amounts. Blueberries are almost devoid of ellagitannins, while proanthocyanidins are present in a varying amounts with different degrees of polymerization; from monomeric flavanols to oligomers (degree of polymerization (DP) 2-10), and to high molecular weight polymers (DP > 10) (Gu et al., 2004). Oligomers in blueberries consist of catechin and epicatechin units that are singly linked $\left[\mathrm{B}_{1}\right.$ (monomer) through $\mathrm{B}_{8}$ (octamer)] (Prior et al., 2001). Terminal units of blueberry polymeric proanthocyanidins consists of epicatechin and catechin, while extension units consist of epicatechin (Gu et al., 2002). The total amount of tannins in blueberries is on average 160 mg/100 g FW (Diaconeasa et al., 2015). Highly polymerized forms of proanthocyanidins dominate in blueberry extracts, accounting for $72 \%$ of the total extractable proanthocyanidins (DP > 10) (Hellström et al., 2009).

The contents of proanthocyanidins in blueberries grown in Sweden varied from 13.9 in the 'Camelia' to $19.8 \mathrm{mg} / 100$ g FW in the 'Duke' cultivar (Liu et al., 2020). Much higher levels were reported by Smeriglio et al. (2017) and Gu et al., (2004) for cultivated blueberries (highbush) 87-274 and 179 $\mathrm{mg} / 100 \mathrm{~g}$ FW, respectively, and wild berries (lowbush) 311$335 \mathrm{mg} / 100 \mathrm{~g} \mathrm{FW}$. However, the literature data is inconsistent. Prior et al. (2001) found that wild blueberries contain higher levels of total procyanidins compared to cultivated berries.

Blueberry processing into products results in remarkable losses of proanthocyanidins. The losses of proanthocyanidins are caused during the large number and complexity of processing steps. Clarified blueberry juices preserve on average $38 \%$ of monomers, $58 \%$ of dimers, $24 \%$ of trimers, $20 \%$ of tetramers and less than $11 \%$ of pentamers of proanthocyanidins present in frozen berries. Octamers were not detectable. Similar losses of compounds were reported for unclarified juices (Rodriguez-Mateos et al., 2014). Regarding the total levels of proanthocyanidins, nonclarified and clarified juices retained $19-36 \%$ and $23-47 \%$ of that in frozen berries (Brownmiller et al., 2009; Howard, et al., 2012).

The greatest retention of proanthocyanidins is expected in simple canning processes in which thawed berries are covered with water or syrup and then pasteurized. In such processes, the berries remain intact and the enzymatic degradation is limited. Oligomers with DP $>3$ were retained less when compared to proanthocyanidin monomers and dimers (Howard et al., 2012). The losses could be a consequence of a preferential binding of the large-molecular-weight proanthocyanidins to cell-wall polymers, which occurred 
after cell disruption by heating and mixing. However, it is also possible that in response to thermal treatment, larger oligomers were depolymerized to monomers and dimers (Brownmiller et al., 2009).

Rodriguez-Mateos et al. (2014) studied the changes in proanthocyanidins content during the baking of a product with freeze-dried wild blueberry powder. They found no differences in total proanthocyanidin content. During the whole process, the content of lower molecular weight oligomers (dimers and trimers) increased by 36 and 28\%, while nonamers and decamers completely disappeared.

Proanthocyanidin content in blueberry products declined during 6 months of storage at $25^{\circ} \mathrm{C}$. Blueberries canned in water retained $38 \%$, blueberries canned in syrup retained $29 \%$, while purees and juices retained less than $11 \%$ of proanthocyanidins. Larger oligomers in processed products were less stable than monomers and dimers (Brownmiller et al., 2009; Howard et al., 2012).

\section{Chokeberry}

The genus Aronia is represented by two species Aronia melanocarpa (Michx.) Elliot (black chokeberry) and Aronia arbutifolia (L.) Pers. known as red chokeberry. Aronia melanocarpa is the predominant commercial chokeberry cultivar and has gained increased popularity due to its assumed health-promoting effects, which have been reviewed by Sidor et al. (2019) and Kokotkiewicz et al. (2010) together with the berries pharmacologically relevant constituents. Chokeberries are very valuable as a food ingredient and are used in the food industry mainly for the production of juice, jam and wine, and as a natural colorant.

The fruits have an astringent taste due to a high tannin content (Wu et al., 2004). They mainly contain polymeric proanthocyanidins (DP > 10) which account for about $66 \%$ to $82 \%$ of total polyphenolic compounds (Oszmiański and Wojdylo, 2005, Denev at al., 2018; Wu et al., 2004). Even higher amounts are present in smaller fruits (Wangensteen et al., 2014) and chokeberry leaves, for which 22\% higher levels of proanthocyanidins were reported when compared to ripe fruits (Teleszko and Wojdylo, 2015). According to literature, their levels in fruits vary from $522 \mathrm{mg} / 100 \mathrm{~g} \mathrm{FW}$ to 3671 mg/100 g FW (Denev et al., 2018; Wu et al., 2004; Taheri et al., 2013), however, no significant differences were reported between black, red and purple (Aronia prunifolia) coloured chokeberry fruits (Taheri et al., 2013). Proanthocyanidins predominated in the berry flesh $(70 \%)$ followed by the skin (25\%) and kernels (5\%) (Mayer-Miebach et al., 2012). An increasing trend in their content was observed with prolonged harvest time (Poyraz Engin and Mert, 2020). Chokeberry proanthocyanidins have been identified exclusively as procyanidin B-type, containing epicatechin as the main monomer unit (Oszmiański and Wojdylo, 2005). Cultivated and wild A. melanocarpa fruits have a similar oligomeric proanthocyanidin composition (Sueiro et al., 2006). Different chokeberry varieties contain 80-95\% extractable proanthocyanidins (Hellström et al., 2009; Taheri et al., 2013), while ellagitannins have not been detected
(Kähkönen et al., 2001). In contrast, the chokeberry leaves, which are not used as functional food, are characterized by high proportions of flavanols (Teleszko and Wojdylo, 2015).

The total proanthocyanidin content ranges from approximately 1408-1579 mg/100 g DW for chokeberry juice to $8192-9586 \mathrm{mg} / 100 \mathrm{~g}$ in pomace (Oszmiański and Wojdylo, 2005; Rodríguez-Werner et al., 2019) and depends on genetic attributes, harvest date, cultivation location and practice, processing and storage. Their levels remain stable upon blanching, and then increase by $11 \%$ after enzyme treatment, probably due to the disruption of cell wall polysaccharides and proteins to which polymeric procyanidins are bound. The higher losses of about $40 \%$ of proanthocyanidins occurred during the pressing operation after which the majority of them remains in the pomace (Mayer-Miebach et al., 2012). Oszmiański and Lachowicz (2016) reported that the content of procyanidin polymers in juices prepared from crushed fruits before processing was higher by over $62 \%$ higher than in juices prepared from non-crushed berries. Juices stored for 6 months at $25{ }^{\circ} \mathrm{C}$, retained more than $90 \%$ of the total proanthocyanidins (Wilkes et al., 2014). They are quite stable as no degradation was noticed after heating purees up to 100 ${ }^{\circ} \mathrm{C}$ for 20 min (Mayer-Miebach et al., 2012).

\section{CONCLUDING REMARKS}

Berry fruits are important sources of tannins. Their content and chemical composition depend on the species, variety, cultivation practice, and treatment before and after harvest. Ellagitannins are found in strawberries and raspberries, but are less common in other berry fruits. The major class of tannins in blueberries and chokeberries are proanthocyanidins, while strawberries are characterized by both ellagitannins and proanthocyanidins. Chokeberries are characterized with the highest content of condensed tannins among 100 plant foods investigated. All these berries can be consumed fresh or processed into purees, juices, syrups, and jams, due to their short shelf life. They also can be preserved by deep freezing or by different drying techniques. Currently, cold storage or freeze-drying is the most effective strategy to preserve the colour and polyphenol content in berries and their products. Tannins are lost during processing to varying degrees, depending on the production technology. In general, processes comprised of more steps (e.g. juice production) result in the greatest losses. As large amounts of bioactive compounds are annually discharged in food by-products, challenges exist to improve the most critical steps and to retain these compounds in berry products. During processing and storage of berry products, the tannin composition is altered. What exactly happens to the various compounds belonging to the class of tannins during these processes is poorly understood and requires further consideration.

\section{REFERENCES}

1. Aaby, K., Mazur, S., Nes, A., \& Skrede, G. (2012). Phenolic compounds in strawberry (Fragaria $\times$ ananassa Duch.) fruits: Composition in 27 cultivars and changes during 
ripening. Food Chemistry, 132, 86-97.

2. Akagi, T., Katayama-Ikegami, A., Suzuki, Y., Yoshida, J., Yamada, M., Sato, A., \& Yonemori, K. (2009). Expression balances of structural genes in shikimate and flavonoid biosynthesis cause a difference in proanthocyanidin accumulation in persimmon (Diospyros kaki) fruit. Planta, 230, 899-915.

3. Alvarez-Suarez, J.M., Giampieri, F., Tulipani, S., Casoli, T., Di Stefano, G., González-Paramás, A.M., SantosBuelga, C., Busco, F., Quiles, J.L., Cordero, M.D., Bompadre, S., Mezzetti, B., \& Battino, M. (2014). Onemonth strawberry-rich anthocyanin supplementation ameliorates cardiovascular risk, oxidative stress markers and platelet activation in humans. The Journal of Nutritional Biochemistry, 25, 289-294.

4. Anttonen, M.J., Hoppula, K.I., Nestby, R., Verheul, M.J., \& Karjalainen, R.O. (2006). Influence of fertilization, mulch color, early forcing, fruit order, planting date, shading, growing environment, and genotype on the contents of selected phenolics in strawberry (Fragaria $\mathrm{x}$ ananassa Duch.) fruits. Journal of Agricultural and Food Chemistry, 54 (7), 2614-2620.

5. Barbehenn, R.V., \& Constabel, C.P. (2011). Tannins in plant-herbivore interactions. Phytochemistry, 72 (13), 1551-1565.

6. Beekwilder, J., Hall, R.D., \& de Vos, C.H. (2005). Identification and dietary relevance of antioxidants from raspberry. BioFactors, 23, 197-205.

7. Bobinaité, R., Viskelis, P., \& Venskutonis, R. (2012). Variation of total phenolics, anthocyanins, ellagic acid and radical scavenging capacity in various raspberry (Rubus spp.) cultivars. Food Chemistry, 132, 1495-1501.

8. Brownmiller, C.R., Howard, L.R., \& Prior, R.L. (2009). Processing and storage effects on procyanidin composition and concentration of processed blueberry products. Journal of Agricultural and Food Chemistry, 57, 1896-1902.

9. Buendia, B., Gil, M.I., Tudela, J.A., Gady, A.L., Medina, J.J., Soria, C., López, J.M., \& Tomás-Barberán, F.A. (2010). HPLC-MS analysis of proanthocyanidin oligomers and other phenolics in 15 strawberry cultivars. Journal of Agriculture and Food Chemistry, 58, 3916-3926.

10. Carbone, F., Preuß, A., De Vos, R., D’Amico, E., Perrotta, G., Bovy, A.G., Martens, S., \& Rosati, C. (2009). Developmental, genetic and environmental factors affect the expression of flavonoid genes, enzymes and metabolites in strawberry fruits. Plant Cell and Environment, 32 (8), 1117-1131.

11. Çekiç, C., \& Özgen, M. (2010). Comparison of antioxidant capacity and phytochemical properties of wild and cultivated red raspberries (Rubus idaeus L.). Journal of Food Composition and Analysis, 23, 540-544.

12. Close, D.C., \& McArthur, C. (2002). Rethinking the role of many plant phenolics - protection from photodamage not herbivores? Oikos, 99, 166-172.

13. Constabel, C.P., Yoshida, K., \& Walker, V. (2014). Diverse ecological roles of plant tannins: plant defense and beyond. In: A. Romani, V. Lattanzio \& S. Quideau (Ed.), Recent Advances in Polyphenol Research (Chapter 5) [E-reader version]. Retrieved from: https://www.
researchgate.net/publication/269277107_Diverse_ Ecological_Roles_of_Plant_Tannins_Plant_Defense_ and_Beyond

14. Crozier, A., Jaganath, I.B., \& Clifford, M.N. (2009). Dietary phenolics: chemistry, bioavailability and effects on health. Natural Product Reports, 26, 1001-1043.

15. De Ancos, B., Ibañez, E., Reglero, G., \& Cano, M.P. (2000). Frozen storage effects on anthocyanins and volatile compounds of raspberry fruit. Journal of Agricultural and Food Chemistry, 48 (3), 873-879.

16. Denev, P., Kratchanova, M., Petrova, I., Klisurova, D., Georgiev, Y., Ognyanov, M., \& Yanakieva, I. (2018). Black chokeberry (Aronia melanocarpa (Michx.) Elliot) fruits and functional drinks differ significantly in their chemical composition and antioxidant activity. Hindawi Journal of Chemistry, 2018, Article ID 9574587.

17. Desjardins, Y.(2014).Humanhealth effects of strawberry: a review of current research. Acta Horticulturae, 1049, 827-838.

18. Diaconeasa, Z., Ranga, F., Rugina, D., Leopold, L., Pop, O., Vodnar, D., Cuibus, L., \& Socaciu., C. (2015). Phenolic content and their antioxidant activity in various berries cultivated in Romania. Food Science and Technology, 72 (1), 99-103.

19. Di Vittori, L., Mazzoni, L., Battino, M., \& Mezzetti, B. (2018). Pre-harvest factors influencing the quality of berries. Scientia Horticulturae, 233, 310-322.

20. Dixon, R.A., \& Sarnala, S. (2020). Proanthocyanidin biosynthesis - a matter of protection. Plant Physiology, 184 (2), 579-591.

21. Fecka, I., Nowicka, A., Kucharska, A.Z., \& SokólŁetowska, A. (2021). The effect of strawberry ripeness on the content of polyphenols, cinnamates, L-ascorbic and carboxylic acids. Journal of Food Composition and Analysis, 95, 103669.

22. Filgueira, D., Molde, D., Fuentealba, C., \& Garcia, D.E. (2017). Condensed tannins from pine bark: a novel wood surface modifier assisted by laccase. Industrial Crops and Products, 103, 185-194.

23. Fraga-Corral, M., Garcia-Oliveira, P., Pereira, A.G., Lourenço-Lopes, C., Jimenez-Lopez, C., Prieto, M.A., \& Simal-Gandara, J. (2020). Technological application of tannin-based extracts. Molecules, 25, 614, 1-27.

24. Fumagalli, M., Sangiovanni, E., Vrhovsek, U., Piazza, S., Colombo, E., Gasperotti, M., Mattivi, F., De Fabiani, E., \& Dell'Agli, M. (2016). Strawberry tannins inhibit IL-8 secretion in a cell model of gastric inflammation. Pharmacological Research, 111, 703-712.

25. Furlan, C.M., Motta, L.B., \& Cursino dos Santos, D.Y.A. (2010). Tannins: What do they represent in plant life? In: G.K. Petridis (Ed.), Tannins: Types, Foods Containing, and Nutrition (pp. 251-263). São Paulo, Brazil. Nova Science Publishers.

26. Gasperotti, M., Masuero, D., Guella, G., Palmieri, L., Martinatti, P., Pojer, E., Mattivi, F., \& Vrhovsek, U. (2013). Evolution of Ellagitannin Content and Profile during Fruit Ripening in Fragaria spp. Journal of Agricultural and Food Chemistry, 61, 8597-8607.

27. Gasperotti, M., Masuero, D., Mattivi, F., \& Vrhovsek, U. (2015). Overall dietary polyphenol intake in a 
bowl of strawberries: The influence of Fragaria spp. In nutritional studies. Journal of Functional Foods, 18, Part B, 1057-1069.

28. Gu, L., Kelm, M.A., Hammerstone, J.F., Beecher, G., Holden, J., Haytowitz, D., Gebhardt, S., \& Prior, R.L. (2004). Concentrations of proanthocynidins in common foods and estimations of normal consumption. The Journal of Nutrition, 134, 613-617.

29. Gu, L., Kelm, M., Hammerstone, J.F., Beecher, G., Cunningham, D., Vannozzi, S., \& Prior, R.L. (2002). Fractionationa of polymeric procyanidins from lowbush blueberry and quantification of procyanidins in selected foods with an optimized normal-phase HPLC-MS fluorescent detection method. Journal of Agricultural and Food Chemistry, 50, 4852-4860.

30. Hellström, J.K., Törrönen, A.R., \& Mattila, P.H. (2009). Proanthocyanidins in common food products of plant origin. Journal of Agricultural and Food Chemistry, 57 (17), 7899-7906.

31. Hidalgo, G.I., \& Almajano, M.P. (2017). Red fruits: extraction of antioxidants, phenolic content and radical scavenging determination: a review. Antioxidants (Basel), 6 (1), 310-322.

32. Howard, L.R., Prior, R.L., Liyanage, R., \& O Lay, J. (2012). Processing and storage effect on berry polyphenols: challenges and implications for bioactive properties. Journal of Agricultural and Food Chemistry, 60 (27), 6678-6693.

33. Izawa, K., Amino, Y., Kohmura, M., Ueda, Y., \& Kuroda, M. (2010). Human - Environment interactions - Taste. In: H. Liu \& L. Mander (Ed.), Comprehensive natural products II (Chapter 4.16.5.1) [E-reader version]. Retrievedfrom:https://www.sciencedirect.com/science/ article/pii/B9780080453828001088?via\%3Dihub

34. Jin, A., Ozga, J.A., Lopes-Lutz, D., Schieber, A., \& Reinecke, D.M. (2012). Characterization of proanthocynidins in pea (Pisum sativum L.), lentil (Lens culinaris L.), and faba bean (Vicia faba L.) seeds. Food Research International, 46, 528-535.

35. Kähkönen, M.P., Hopia, A.I., \& Heinonen, M. (2001). Berry phenolics and their antioxidant activity. Journal of Agricultural and Food Chemistry, 49(8), 49076-4082.

36. Kao, Y.Y., Harding, S.A., \& Tsai, C.J. (2002). Differential expression of two distinct ohenylalanine ammonialyase genes in condensed tannin-accumulating and lignifying cells of quaking aspen. Plant Physiology, 130, 796-807.

37. Karlińska, E., Masny, A., Cieślak, M., Macierzyński, J., Pecio, L., Stochmal, A., \& Kosmala, M. (2021). Ellagitannins in roots, leaves, and fruits of strawberry (Fragaria $\times$ ananassa Duch.) vary with developmental stage and cultivar. Scientia Horticulturae, 275, 109665.

38. Khanbabaee, K., \& Van Ree, T. (2001). Tannins: classification and definition. Natural Product Reports, 18, 641-649.

39. Kokotkiewicz, A., Jaremicz, Z., \& Luczkiewicz, M. (2010). Aronia plants: a review of traditional use, biological activities, and perspectives for modern medicine. Journal of Medicinal Food, 13(2), 255-269.

40. Koponen, J.M., Happonen, A.M., Mattila, P.H., \&
Tőrrőnen, A.R. (2007). Contents of anthocaynins and ellagitannins in selected foods consumed in Finland. Journal of Agricultural and Food Chemistry, 55, 16121619.

41. Krauze-Baranowska, M., Gtód, D., Kula, M., Majdan, M., \& Hatasa, R. (2014). Chemical composition and biological activity of Rubus idaeus shoots - a traditional herbal remedy of Eastern Europe. BMC Complementary Medicine and Therapies, 14, 480.

42. Krzyzowska, M., Tomaszewska, E., Ranoszek-Soliwoda, K., Bien, K., Orlowski, P., Celichowski, G., \& Grobelny, J. (2017). Tannic acid modification of metal nanoparticles: possibility for new antiviral applications. In: E. Andronescu \& A. Grumezescu (Ed.), Nanostructures for oral medicine (Chapter 12) [E-reader version]. Retrieved from: https://www.sciencedirect.com/science/article/ pii/B9780323477208000134

43. Kula, M., Majdan, M., Gtód, D., \& Krauze-Baranowska, M. (2016). Phenolic composition of fruits from different cultivars of red and black raspberries grown in Poland. Journal of Food Composition and Analysis, 52, 74-82.

44. Lamy, E., Pinheiro, C., Rodrigues, L., Capela e Silva, F., Silva Lopes, O., Tavares, S., \& Gaspar, R. (2016). Determinants of tannin-rich food and beverage consumption: oral perception vs. psychosocial aspects. In C.A. Combs (Ed.), Tannins: Biochemistry, food sources and nutritional properties, [E-reader version] (pp. 29-58). Retrieved from: file://C:/Users/uporabnik/ Downloads/Proofs_ChapterID_37173_6x91.pdf

45. Landete, J.M. (2011). Ellagitannins, ellagic acid and their derived metabolites: A review about source, metabolism, functions and health. Food Research International, 44(5), 1150-1160.

46. Leafy place. (2019). 23 Types of Berries: List of berries with their picture and name. Retrieved from https:// leafyplace.com/types-of-berries/.

47. Lees, G.L., Suttill, N.H., \& Gruber, M.Y. (1993). Condensed tannins in sainfoin.1. A histological and cytological survey of plant tissues. Canadian Journal of Botany, 71, 1147-1152.

48. Lepiniec, L., Debeaujon, I., Routaboul, J.-M., Baudry, A., Pourcel, L., Nesi, N., \& Caboche, M. (2006). Genetics and biochemistry of seed flavonoids. Annual Review of Plant Biology, 57, 405-430.

49. Liu, J., Hefni, M.E., \& Witthőft, C.M. (2020). Characerization of flavonoid compounds in common Swedish berry species. Foods, 9(3), 358.

50. Määttä-Riihinen, K.R., Kamal-Eldin, A., \& Tőrrőnen, A.R. (2004). Identification and quantification of phenolic compound in berries of Fragaria and Rubus species (Family Rosaceae). Journal of Agricultural and Food Chemistry, 52, 6178-6187.

51. Manganaris, G.A., Goulas, V., Vicente, A.R., \& Terry, L.A. (2014). Berry antioxidants: small fruits providing large benefits. Journal of the Science of Food and Agriculture, 94(5), 825-833.

52. Matus, J.T., Loyola, R., Vega, A., Peña-Neira, A., Bordeu, E., Arce-Johnson, P., \& Alcalde, J.A. (2009). Postveraison sunlight exposure induces MYB-mediated transcriptional regulation of anthocyanin and flavonol 
synthesis in berry skins of Vitis vinifera. Journal of Experimental Botany, 60(3), 853-867.

53. Mayer-Miebach, E., Adamiuk, M., \& Behsnilian, D. (2012). Stability of chokeberry bioactive polyphenols during juice processing and stabilization of a polyphenolrich amterial from the by-product. Agriculture, 2(3), 244-258.

54. Mazur, S.P., Nes, A., Wold, A.-B., Remberg, S.F., \& Aaby, K. (2014). Quality and chemical composition of ten red raspberry (Rubus idaeus L.) genotypes during three harvest seasons. Food Chemistry, 160, 233-240.

55. McKenzie, B.E., \& Peterson, C.S. (1995). Root browning in Pinus banksiana and Eucalyptus pilularis Sm.1. Anatomy and permeability of the white and tannin zones. Botanica Acta, 108, 127-137.

56. Mena, P., Calani, L., Bruni, R., \& Del Rio, D. (2015). Bioactivation of High-Molecular-Weight Polyphenols by the Gut Microbiome. Diet-Microbe Interactions in the Gut, 73-101.

57. Milczarek, A., Sójka, M., \& Klewicki, R. (2021). Transfer of ellagitannins to unclarified juices and purees in the processing of selected fruits of the Rosaceae family. Food Chemistry, 344, 128684.

58. Milivojević, J., Maksimović, V., Nikolić, M., Bogdanović, J., Maletić, R., \& Milatović, D. (2010). Chemical and antioxidant properties of cultivated and wild Fragaria and Rubus berries. Journal of Food Quality, 34, 1-9.

59. Milivojević, J.M., Nikolić, M.D., Dradišić Maksimović, J., \& Radivojević, D.D. (2011). Generative and fruit quality characteristics of primocane fruiting red raspberry cultivars. Turkish Journal of Agriculture and Forestry, 35, 289-296.

60. Mullen, W., McGinn, J., Lean, M.E.J., MacLean, M.R., Gardner, P., Duthie, G.G., Yokota, T., \& Crozier, A. (2002a). Ellagitannins, flavonoids, and other phenolics in red raspberries and their contribution to antioxidant capacity and vasorelaxation properties. Journal of Agricultural and Food Chemistry, 50, 5191-5196.

61. Mullen, W., Stewart, A.J., Lean., M.E.J., Gardner, P., Duthie, G.G., \& Crozier, A. (2002b). Effect of freezing and storage on the phenolics, ellagitannins, flavonoids, and antioxidant capacity of red raspberries. Journal of Agricultural and Food Chemistry, 50, 5197-5201.

62. Mullen, W., Yokota, T., Lean, M.E.J., \& Crozier A. (2003). Analysis of ellagitannins and conjugates of ellagic acid and quercetin in raspberry fruits by LCMSn. Phytochemistry, 64(2), 617-624.

63. Nowicka, A., Kucharska, A.Z., Sokól-Łetowska, A., \& Fecka, I. (2019). Comparicon of polyphenol content and antioxidant capacity of strawberry fruit from 90 cultivars of Fragaria $\times$ ananassa Duch. Food Chemistry, 270, 32-46.

64. Okuda, T., Yoshida, T., Hatano, T., Iwasaki, M., Kubo, M., Orime, T., Yoshizaki, M., \& Naruhashi, N. (1992). Hydrolysable tannins as chemotaxonomic markers in the rosaceae. Phytochemistry, 32(9), 3091-3096.

65. Oliveira, M., Rodrigues, C.M., \& Teixeira, P. (2019). Microbiological quality of raw berries and their products: A focus on foodborne pathogens. Heliyon, 5 (12), e02992.
66. Oszmiański, J., \& Lachowicz S. (2016). Effect of the production of dried fruits and juice from chokeberry (Aronia melanocarpa L.) on the content and antioxidative activity of bioactive compounds. Molecules, 21, 1098.

67. Oszmiański, J., \& Wojdylo, A. (2005). Aronia melanocarpa phenolics and their antioxidant activity. European Food Research and Technology, 221, 809-813.

68. Oszmiański, J., \& Wojdylo, A. (2009). A comparative study of phenolic content and antioxidant activity of strawberry puree, clear, and cloudy juices. European Food Research and Technology, 228(4), 623-631.

69. Piccolo, E.L., Martìnez-Garcìa, L., Landi, M., Guidi, L., Massai, R., \& Remorini, D. (2020). Influences of postharvest storage and processing techniques on antioxidant and nutraceutical properties of Rubus idaeus 1.: A mini-review. Horticulturae, 6(4), 105.

70. Poyraz Engin, S., \& Mert, C. (2020). The effects of harvesting time on the physicochemical components of aronia berry. Turkish Journal of Agriculture and Forestry, 44(4), 361-370.

71. Prida, A., \& Puech, J.-L. (2006). Influence of geographical origin and botanical species on the content of extractives in American, French, and East European oak woods. Journal of Agricultural and Food Chemistry, 54, 81158126.

72. Prior, R.L., \& Gu, L. (2005). Occurrence and biological significance of proanthocynidins in the American diet. Phytochemistry, 66, 2264-80.

73. Prior, R.L., Lazarus, S.A., Cao, G., Muccitelli, H., \& Hammerstone, J.F. (2001). Identification of procyanidins and anthocyanins in blueberries and cranberries (Vaccinium spp.) using high-performance liquid chromatography/mass spectrometry. Journal of Agricultural and Food Chemistry, 49, 1270-1276.

74. Rodriguez-Mateos, A., Cifuentes-Gomez, T., George, T.W., \& Spencer, J.P.E. (2014). Impact of cooking, proving, and baking on the (poly)phenol content of wild bluberry. Journal of Agricultural and Food Chemistry, 62, 3979-3986.

75. Rodríguez-Werner, M., Winterhalter, P., \& Esatbeyoglu, T. (2019). Phenolic composition, radical scavenging activity and an approach for authentication of Aronia melanocarpa berries, juice and pomace. Journal of Food Science, 84(7), 1791-1798.

76. Shukitt-Hale, B., Carey, A.N., Jenkins, D., Rabin, B.M., \& Joseph, J.A. (2007). Beneficial effects of fruit extracts on neuronal function and behaviour in a rodent model of accelerated aging. Neurobiology of Aging, 28, 11871194.

77. Sidor, A., Drożdżyńska, A., \& Gramza-Michatowska, A. (2019). Black chokeberry (Aronia melanocarpa) and its products as potential health-promoting factors - An overview. Trends in Food Science \& Technology, 89, 4560.

78. Sieniawska, E., \& Baj, T. (2017). Tannins. In: S. Badal \& R. Delgoda (Ed.), Pharmacognosy (Chapter 10) [E-reader version]. Retrieved from: https://www.sciencedirect.com/science/article/pii/ B978012802104000010X?via\%3Dihub

79. Smeriglio, A., Barreca, D., Bellocco, E., \& Trombetta, D. 
(2017). Proanthocyanidins and hydrolysable tannins: occurrence, dietary intake and pharmacological effects. British Journal of Pharmacology, 174 (11), 1244-1262.

80. Sójka, M., Macierzyński, J., Zaweracz, W., \& Buczek, M. (2016). Transfer and mass balance of ellagitannins, anthocyanins, flavan-3-ols and flavonols during the processing of red raspberries (Rubus idaeus L.) to juice. Journal of Agricultural and Food Chemistry, 64(27), 5549-63.

81. Sparzak, B., Merino-Arevalo, M., Vander Heyden, Y., Krauze-Baranowska, M., Majdan, M., Fecka, I., Gtód, D., \& Bączek, T. (2010). HPLC analysis of polyphenols in the fruits of Rubus idaeus 1. (Rosaceae). Natural Product Research, 24(19), 1811-1822.

82. Sueiro, L., Yousef, G.G., Seigler, D., De Mejia, E.G., Grace, M.H., \& Lila, M.A. (2006). Chemopreventive potential of flavonoid extracts from plantation-bred and wild Aronia melanocarpa (Black chokeberry) fruits. Journal of Food Science, 71, 480-488.

83. Swanson, B.G. (2003). Tannins and polyphenols. In: B. Caballero (Ed.), Encyclopedia of food sciences and nutrition (Second edition) [E-reader version]. (pp. 57295733). Retrieved from: https://www.sciencedirect.com/ sdfe/pdf/download/eid/3-s2.0-B012227055X011780/ first-page-pdf

84. Taheri, R., Connolly, B.A., Brand, M.H., \& Bolling, B.W. (2013). Underutilized chokeberry (Aronia melanocarpa, Aronia arbutifolia, Aronia prunifolia) accessions are rich sources of anthocyanins, flavonoids, hydroxycinnamic acids, and proanthocyanidins. Journal of Agricultural and Food Chemistry, 61, 8581-8588.

85. Teleszko, M., \& Wojdyto, A. (2015). Comparison of phenolic compounds and antioxidant potential between selected edible fruits and their leaves. Journal of Functional Foods, 14, 736-746.

86. Türkben, C., Sariburun, E., Demir, C., \& Uylaşer, V. (2010). Effect of freezing and frozen storageon phenolic compounds of raspberry and blackberry cultivars. Food Analytical Methods, 3, 144-153.

87. Uleberg, E., Rohloff, J., Jaakola, L., Trôst, K., Junttila, O., Häggman, H., \& Martinussen, I. (2012). Effects of temperature and photoperiod on yield and chemical composition of northern and southern clones of bilberry (Vaccinium myrtillus L.). Journal of Agricultural and Food Chemistry, 60(42), 10406-10414.

88. Vrhovsek, U., Giongo, L., Mattivi, F., \& Viola, R. (2008). A survey of ellagitannin content in raspberry and blackberry cultivars grown in Trentino (Italy). European Food Research and Technology, 226, 817-824.

89. Vrhovsek, U., Palchetti, A., Reniero, F., Guillou, C., Maduero, D., \& Mattifi, F. (2006). Concentration and mean degree of polymerization of Rubus ellagitannins evaluated by optimized acid methanolysis. Journal of Agricultural and Food Chemistry, 54, 4469-4475.

90. Wang, S.Y., Chen, C.T., \& Wang, C.Y. (2009). The influence of light and maturity on fruit quality and flavonoid content of red raspberries. Food Chemistry, 112(3), 676-684.

91. Wangensteen, H., Bräunlich, M., Nikolic, V., Malterud K.E., Simestad, R., \& Barsett, H. (2014). Anthocyanins, proanthocyanidins and total phenolics in four cultivars of aronia: Antioxidant and enzyme inhibitory effects. Journal of Functional Foods, 7(1), 746-752.

92. Wilkes, K., Howard, L.R., Brownmiller, C., \& Prior, R.L. (2014). Changes in chokeberry (Aronia melanocarpa L.) polyphenols during juice processing and storage. Journal of Agricultural and Food Chemistry, 62, 40184025.

93. Wu, X., Gu, L., Prior, R.L., \& McKay, S. (2004). Characterization ofanthocyaninsand proanthocyanidins in some cultivars of Ribes, Aronia and Sambucus and their antioxidant capacity. Journal of Agricultural and Food Chemistry, 52(26), 7846-7856.

94. Zafrilla, P., Ferreres, F., \& Tomás-Barberán, F.A. (2001). Effect of processing and storage on the antioxidant ellagic acid derivatives and flavonoids of red raspberry (Rubus idaeus) jams. Journal of Agricultural and Food Chemistry, 49(8), 3651-3655.

95. Zoratti, L., Karppinen, K., Escobar, A.L., Häggman, H., \& Jaakola, L. (2014). Light-controlled flavonoid biosynthesis in fruits. Frontiers in Plant Science, 5, 534. 


\section{Tanini v jagodičevju - pregled}

\section{IZVLEČEK}

Tanini so skupina polifenolnih spojin, ki jih kot sekundarne metabolite sintetizirajo in akumulirajo višje rastline. Delimo jih na hidrolizabilne tanine in proantocianidine. Prisotni so v številnih rastlinskih tkivih v obliki različnih struktur in v različnih količinah. Pregledni članek ponuja kratek pregled o porazdelitvi taninov v rastlinah in povzema trenutno znane izsledke o taninih $\mathrm{v}$ jagodah, malinah, borovnicah, ki so najpogosteje gojeno in konzumirano jagodičevje ter aroniji, ki je postala priljubljena $\mathrm{v}$ zadnjih desetletjih. Povzeti so tudi učinki predelave in skladiščenja na taninsko sestavo in njihova vsebnost v izdelkih.

Ključne besede: elagitanini, proantocianidini, jagode, maline, borovnice, aronija 